\title{
THE EFFECT OF CYTOCHROME C UPON THE RESPIRATION OF TISSUE SLICES
}

\author{
By WILLIAM R. CHRISTENSEN AND OLOF H. PEARSON 1 \\ (From the Department of Biological Chemistry, Harvard Medical School, Boston)
}

(Received for publication April 25, 1947)

Recent studies of the effect of added Cytochrome $C$ upon the respiration of tissue homogenates $(1,2)$ have led to the conclusion that the organ content of this respiratory enzyme is less than optimum $(2,3)$. This has led to intensive investigation of the results of its parenteral administration to normal and anoxic animals and its effectiveness in clinical conditions characterized by tissue anoxia (2 to 8 ). In view of the theoretical and practical implications of these observations, the effect of Cytochrome $\mathrm{C}$ upon the respiration of normal and anoxic tissue slices has been investigated.

\section{EXPERIMENTAL}

Wistar strain rats, varying in weight from 100 to 400 grams, were used throughout this study. They were fed Purina Dog Chow ad lib, and were not fasted before sacrifice. In all experiments the rats were killed by a sharp blow on the head. The heart or liver was excised as rapidly as possible and placed in an iced, phosphate-buffered medium which contained 0.2 per cent glucose and whose ionic composition was as follows:

\begin{tabular}{c|c|c|c}
\hline \hline Cation & Concentration & Anion & Concentration \\
\hline & meq. per $l$. & & $\mathrm{Cl}$ \\
$\mathrm{Na}$ & 150 & $\mathrm{Heq.} \mathrm{per} l$. \\
$\mathrm{K}$ & 4 & $\mathrm{HOO}_{4}$ & 142 \\
$\mathrm{Ca}$ & 2 & $\mathrm{H}_{2} \mathrm{PO}_{4}$ & 15 \\
$\mathrm{Mg}$ & 1 & & \\
\hline
\end{tabular}

The $\mathrm{pH}$ was 7.4.

Liver slices approximately $0.5 \mathrm{~mm}$. in thickness were. prepared by means of a modified Stadie and Riggs tissue microtome (9). Heart slices of similar thickness were made by hand, using a razor blade as cutting tool and a glass slide as a template. Both types of slices were placed in an aliquot of well-oxygenated incubation medium at room temperature until placed in Warburg vessels.

Respiration was measured at $37^{\circ} \mathrm{C}$. by the direct method of Warburg. Each vessel contained $3.0 \mathrm{ml}$. of the incubation medium in the outer compartment and $0.2 \mathrm{ml}$. of 10 per cent $\mathrm{KOH}$ plus filter paper in the center cup. Approximately $20 \mathrm{mgm}$. of tissue (dry weight) were

\footnotetext{
${ }^{1}$ Supported in part by a grant from the Life Insurance Medical Research Fund.
}

used in each vessel. The vessels were equilibrated with varying mixtures of oxygen and nitrogen while being shaken in the constant temperature bath at the rate of 120 oscillations per minute. Readings were started about 30 minutes after the animals had been sacrificed. The tissue was removed at the end of the experiment and the dry weight obtained. All determinations were made in duplicate or triplicate. The results for the liver slices usually checked within 10 per cent and for the heart slices within 15 per cent. Respiration rate curves were plotted and the best linear relationship obtained from the observed points. Results were expressed as $\mathrm{QO}_{z}$ (mm. ${ }^{3}$ of $\mathrm{O}_{2}$ per mgm. of dry weight of tissue per hour).

Cytochrome $\mathrm{C}$ was prepared according to the method of Keilin and Hartree (10). The preparation was carried only as far as the stage known to yield a product containing .34 per cent iron. The purity of the material was based on its spectrophotometric analysis using a Beckmann spectrophotometer with $1 \mathrm{~cm}$. cells. The optical density of a solution containing a known amount of the preparation was determined at a wave length of $550 \mathrm{~m} \mu$ and a spectral interval of $1.5 \mathrm{~m} \mu$. The concentration was then calculated using the absorption constant proposed by Drabkin (11). The preparation used consisted of 55 per cent Cytochrome $C$ and 45 per cent sodium chloride. Solutions were freshly prepared from the lyophilized powder on the day of each experiment. The amount of Cytochrome $\mathrm{C}$ added to the suspending medium was equal to or in excess of the normal concentration in the tissue studied (12).

\section{RESULTS}

The results of respiration measurements on liver slices at varying oxygen tensions with and without added Cytochrome $\mathrm{C}$ are summarized in Table I. Respiration was measured over a period of 1 hour in slices equilibrated with 2.5 to 20 per cent oxygen, following which 100 per cent oxygen was introduced and the respiration during recovery measured for a second hour. In addition, liver slices were equilibrated with commercial nitrogen (ca. 0.5 per cent oxygen) for a period of 40 minutes following which 100 per cent oxygen was introduced and the rate of respiration measured for 1 hour. During the period of equilibration with nitrogen, there was no measurable respiration. It is apparent from the data presented 
TABLE I

Rat liver

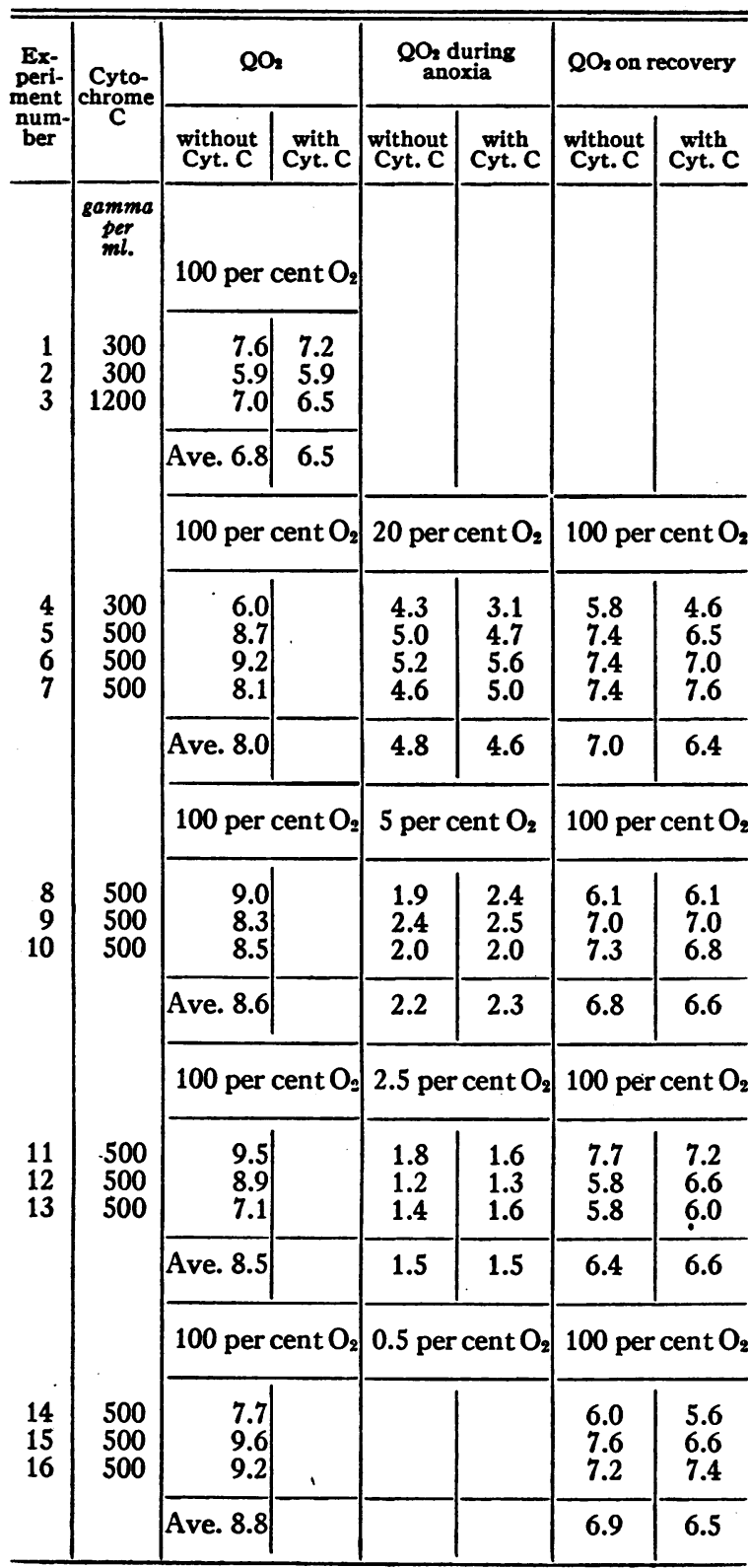

that the addition of Cytochrome $C$ had no demonstrable effect upon the rate of respiration of surviving liver slices. The metabolism of those slices which were exposed to oxygen concentrations below 100 per cent was reduced in all cases. The magnitude of the depression was roughly proportional to the oxygen tension. Moreover, restoration of such anoxic slices to an atmosphere of pure oxygen resulted in a marked increase in the $\mathrm{QO}_{2}$. All re- turned to a level of approximately 6.5. However, the presence of Cytochrome $\mathrm{C}$ in concentration of 500 gamma per $\mathrm{ml}$. did not cause an increase in oxygen consumption either during the period of exposure to low oxygen tension or after the tissue was returned to an atmosphere of pure oxygen. The oxygen consumption of liver tissue subjected to varying degrees of anoxia was in no way affected by the presence of greater than physiological

TABLE II

Rat heart

\begin{tabular}{|c|c|c|c|c|c|c|c|}
\hline \multirow{2}{*}{$\begin{array}{c}\text { Ex- } \\
\text { peri- } \\
\text { ment } \\
\text { num } \\
\text { ber }\end{array}$} & \multirow{2}{*}{$\begin{array}{c}\text { Cyto- } \\
\text { chrome } \\
\text { C }\end{array}$} & \multicolumn{2}{|l|}{$\mathbf{Q O}_{2}$} & \multicolumn{2}{|c|}{$\underset{\text { anoxia }}{\mathrm{QO}_{2} \text { during }}$} & \multicolumn{2}{|c|}{$\mathbf{Q O}_{2}$ on recovery } \\
\hline & & $\begin{array}{l}\text { without } \\
\text { Cyt. C }\end{array}$ & with & $\begin{array}{l}\text { without } \\
\text { Cyt. C }\end{array}$ & Cyith & $\begin{array}{l}\text { without } \\
\text { Cyt. C }\end{array}$ & $\begin{array}{c}\text { with } \\
\text { Cyt. C }\end{array}$ \\
\hline \multirow{4}{*}{$\begin{array}{l}1 \\
2\end{array}$} & $\begin{array}{c}\text { gamma } \\
\text { per } \\
\text { mil. }\end{array}$ & \multicolumn{2}{|c|}{100 per cent $\mathrm{O}_{2}$} & . & & & \\
\hline & $\begin{array}{l}500 \\
300 \\
900 \\
500 \\
500\end{array}$ & $\begin{array}{r}7.7 \\
9.0 \\
11.1 \\
12.7\end{array}$ & $\begin{array}{r}6.1 \\
7.1 \\
8.2 \\
9.6 \\
13.2\end{array}$ & & & & \\
\hline & & Ave. 10.1 & 8.8 & & & & \\
\hline & & 100 per ce & ent $\mathrm{O}_{2}$ & 20 per & ent $\mathrm{O}_{2}$ & 100 per & $\operatorname{cent} \mathrm{O}_{2}$ \\
\hline \multirow[t]{3}{*}{$\begin{array}{l}5 \\
6 \\
7 \\
8\end{array}$} & $\begin{array}{l}500 \\
500 \\
500 \\
500\end{array}$ & $\begin{array}{l}10.7 \\
12.3 \\
12.0 \\
11.5\end{array}$ & & $\begin{array}{l}3.6 \\
4.9 \\
4.3 \\
4.3\end{array}$ & $\begin{array}{l}3.3 \\
4.5 \\
4.2 \\
3.4\end{array}$ & $\begin{array}{l}4.5 \\
4.8 \\
5.7 \\
6.6\end{array}$ & $\begin{array}{l}4.6 \\
6.8 \\
5.4 \\
5.6\end{array}$ \\
\hline & & Ave. 11.6 & & 4.3 & 3.9 & 5.4 & 5.6 \\
\hline & & 100 per $c$ & ent $\mathrm{O}_{2}$ & 10 per & $\operatorname{ent} \mathrm{O}_{2}$ & 100 per & $\operatorname{cent} \mathrm{O}_{2}$ \\
\hline \multirow[t]{3}{*}{$\begin{array}{r}9 \\
10 \\
11 \\
12\end{array}$} & $\begin{array}{l}500 \\
500 \\
500 \\
500\end{array}$ & $\begin{array}{l}7.1 \\
9.8 \\
6.4 \\
7.7\end{array}$ & & $\begin{array}{l}1.8 \\
2.0 \\
2.0 \\
2.5\end{array}$ & $\begin{array}{l}1.4 \\
2.0 \\
2.1 \\
2.4\end{array}$ & $\begin{array}{l}3.5 \\
3.3 \\
3.9 \\
2.5\end{array}$ & $\begin{array}{l}3.6 \\
3.6 \\
3.7 \\
3.6\end{array}$ \\
\hline & & Ave. 7.8 & & 2.1 & 2.0 & 3.3 & 3.6 \\
\hline & & 100 per $c$ & ent $\mathrm{O}_{y}$ & 5 per $c$ & ent $\mathrm{O}_{2}$ & 100 per & $\operatorname{cent} \mathrm{O}_{3}$ \\
\hline \multirow[t]{2}{*}{13} & 500 & 8.6 & & 0.8 & 0.7 & 2.9 & 2.0 \\
\hline & & 100 per $c$ & ent $\mathrm{O}_{\varepsilon}$ & 0.5 per & cent $\mathrm{O}_{2}$ & 100 per & cent $\mathrm{O}_{2}$ \\
\hline \multirow[t]{2}{*}{$\begin{array}{l}14 \\
15 \\
16 \\
17\end{array}$} & $\begin{array}{l}500 \\
500 \\
500 \\
500\end{array}$ & $\begin{array}{r}11.1 \\
12.7 \\
11.5 \\
6.9\end{array}$ & & & & $\begin{array}{l}3.7^{*} \\
3.7^{*} \\
4.3 \\
2.7\end{array}$ & $\begin{array}{l}3.4^{*} \\
3.9^{*} \\
4.3 \\
3.2\end{array}$ \\
\hline & & Ave. 10.6 & & & & 3.6 & 3.7 \\
\hline
\end{tabular}

* Single determination. 
concentrations of Cytochrome $\mathrm{C}$ in the suspending medium.

Table II comprises a summary of essentially similar data resulting from studies of heart slices. It is apparent that the metabolism of heart slices was depressed by anoxia to a greater extent than in the case of liver slices exposed to the same oxygen tension. However, they did not show the same degree of recovery when returned to an atmosphere of 100 per cent oxygen. Cytochrome $C$ had no effect upon the respiration of heart slices under any of the conditions considered.

\section{CONCLUSIONS}

1. The addition of Cytochrome $C$ to the incubation medium did not alter the rate of oxygen consumption of surviving liver or heart slices equilibrated with 100 per cent oxygen.

2. The reduction of respiration of heart and liver slices induced by lowering the oxygen tension was not affected by the addition of Cytochrome $\mathrm{C}$ to the suspending medium.

3. The presence of Cytochrome $\mathrm{C}$ in the incubation medium of anoxic tissue slices did not affect their respiration after restoration to an atmosphere of 100 per cent oxygen.

4. The failure of added Cytochrome $C$ to affect the rate of respiration of surviving tissue slices may have been due to non-penetration of Cytochrome $\mathrm{C}$ into the tissue cells or, if it penetrated, the increased concentration of Cytochrome $\mathrm{C}$ did not stimulate the rate of oxygen consumption.

The authors wish to express their appreciation to Professor A. Baird Hastings for his support and guidance.

\section{BIBLIOGRAPHY}

1. Schneider, W. C., and Potter, V. R., The assay of animal tissues for respiratory enzymes; succinic dehydrogenase and cytochrome oxidase. J. Biol. Chem., 1943, 149, 217.

2. Proger, S., Dekaneas, D. J., and Schmidt, G., Some observations of the effect of injected Cytochrome C in animals. J. Clin. Invest., 1945, 24, 864.

3. Proger, S., Dekaneas, D., and Schmidt, G., The increase of Cytochrome C content of organs following its parenteral injection. J. Clin. Invest., 1944, 23, 949.

4. Proger, S., Dekaneas, D., and Schmidt, G., The effects of anoxia and of injected Cytochrome $C^{\prime}$ on the content of easily hydrolyzable phosphorus in rat organs. J. Biol. Chem., 1945, 160, 233.

5. Proger, S., Some effects of injected Cytochrome C in animals and man. Bull. New England M. Center, 1945, 7, 1.

6. Proger, S., and Dekaneas, D., Some further observations on parenteral use of Cytochrome $C$ with special reference to cerebral anoxia and shock. Bull. New England M. Center, 1945, 7, 149.

7. Proger, S., and Dekaneas, D., The use of Cytochrome C in combating tissue anoxia. Science, 1946, 104, 389.

8. Proger, S., and Dekaneas, D., Some effects of injected Cytochrome $\mathrm{C}$ in myocardial and cerebral anoxia in man. J. of Ped., 1946, 29, 729.

9. Stadie, W. C., and Riggs, B. C., Microtome for the preparation of tissue slices for metabolic studies of surviving tissues in vitro. J. Biol. Chem., 1944, $154,687$.

10. Keilin, D., and Hartree, E. F., Purification and properties of Cytochrome C. Biochem. J., 1945, 39, 289.

11. Drabkin, D. L., Spectrophotometric studies. J. Biol. Chem., 1941, 140, 373.

12. Crandall, M. W., and Drabkin, D. L., Cytochrome C in regenerating rat liver and its relation to other pigments. J. Biol. Chem., 1946, 166, 653. 